\title{
SELECTIVE LEACHING AND SURFACE PROPERTIES OF TiNiFe SHAPE-MEMORY ALLOYS
}

\author{
SELEKTIVNO IZPIRANJE IN POVRŠINSKE LASTNOSTI ZLITIN \\ TiNiFe S SPOMINOM
}

\author{
Shih-Hang Chang, Jyun-Sian Liou, Bo-Yen Huang \\ National I-Lan University, Department of Chemical and Materials Engineering, I-Lan 260, Taiwan \\ shchang@niu.edu.tw \\ Prejem rokopisa - received: 2015-09-02; sprejem za objavo - accepted for publication: 2016-04-21
}

doi:10.17222/mit.2015.269

\begin{abstract}
This study investigated the selective leaching and surface characteristics of $\mathrm{Ti}_{50} \mathrm{Ni}_{50-\mathrm{x}} \mathrm{Fe}_{\mathrm{x}}(x=1,2$, and 3$)$ shape-memory alloys using inductively coupled plasma-mass spectrometry, X-ray diffractometry, electrochemical tests and X-ray photoelectron spectroscopy. According to our results, the concentrations of $\mathrm{Ni}$ and Fe ions selectively leached from each specimen were considerably higher than that of Ti ions. Electrochemical tests revealed a gradual deterioration in the corrosion resistance of the $\mathrm{Ti}_{50} \mathrm{Ni}_{50-x} \mathrm{Fe}_{\mathrm{x}} \mathrm{SMAs}$ as the $\mathrm{Fe}$ content in the alloys was increased. X-ray photoelectron-spectroscopy results indicate that the surface of each specimen is primarily made up of a passive $\mathrm{TiO}_{2}$ film. $\mathrm{NiO}$ and $\mathrm{Fe}_{2} \mathrm{O}_{3}$ oxides, which also formed on the surfaces of the $\mathrm{Ti}_{50} \mathrm{Ni}_{50-x} \mathrm{Fe}_{\mathrm{x}} \mathrm{SMAs}$, caused a deterioration of the uniformity, undermining the protective effect of the $\mathrm{TiO}_{2}$ films, resulting in a highly selective leaching of the $\mathrm{Ni}$ and $\mathrm{Fe}$ ions. The $\mathrm{Ti}_{50} \mathrm{Ni}_{50-x} \mathrm{Fe}_{\mathrm{x}} \mathrm{SMAs}$ exhibit a number of favourable properties compared to the other SMAs; however, high concentrations of selectively leached Ni and Fe ions may pose a risk in biomedical applications, particularly when used as implant materials.
\end{abstract}

Keywords: TiNiFe shape-memory alloys, biomaterials, selective leaching, corrosion, X-ray photoelectron spectroscopy

$\mathrm{V}$ študiji je proučevano selektivno izpiranje in značilnosti površine zlitine s spominom $\mathrm{Ti}_{50} \mathrm{Ni}_{50-\mathrm{x}} \mathrm{Fe}_{\mathrm{x}}(x=1,2$, in 3 ), z uporabo masne spektrometrije $\mathrm{z}$ induktivno sklopljeno plazmo, rentgensko difrakcijo, elektrokemijskimi preizkusi in rentgensko fotoelektronsko spektroskopijo. Rezultati kažejo, da je bila koncentracija selektivno izpranih Ni in Fe ionov iz vsakega vzorca veliko večja kot pa Ti ionov. Elektrokemijski preizkusi so pokazali postopno zmanjšanje korozijske odpornosti $\mathrm{Ti}_{50} \mathrm{Ni}_{50-\mathrm{x}} \mathrm{Fe}_{\mathrm{x}}$ SMA, ko je vsebvnost Fe v zlitinah naraščala. Rezultati rentgenske fotoelektronske spektroskopije kažejo, da je površina vseh vzorcev predvsem sestavljena iz pasivnih $\mathrm{TiO}_{2}$ plasti. $\mathrm{NiO}$ in $\mathrm{Fe}_{2} \mathrm{O}_{3}$ oksidi, ki so tudi nastali na površini $\mathrm{Ti}_{50} \mathrm{Ni}_{50-\mathrm{x}} \mathrm{Fe}_{\mathrm{x}} \mathrm{SMAs}_{\mathrm{N}}$ poslabšajo enotnost in ogrožajo varovalno plast iz $\mathrm{TiO}_{2}$ prevlek, kar ima za posledico bolj selektivno izpiranje ionov Ni in Fe. $\mathrm{Ti}_{50} \mathrm{Ni}_{50-\mathrm{x}} \mathrm{Fe}_{\mathrm{x}}$ SMAs vsebuje številne ugodne lastnosti v primerjavi z drugimi SMA; vendar pa velika koncentracija selektivno izpranih $\mathrm{Ni}$ in $\mathrm{Fe}$ ionov lahko predstavlja tveganje pri biomedicinski uporabi, posebno pri implantiranih materialih.

Ključne besede: TiNiFe zlitine s spominom, biomateriali, selektivno izpiranje, korozija, rentgenska fotoelektronska spektroskopija

\section{INTRODUCTION}

Nickel-titanium shape-memory alloys (TiNi SMAs) are widely used in advanced engineering applications due to their favourable shape memory and superelastic properties. ${ }^{1}$ Most TiNi SMAs further exhibit a low cytotoxicity and a good biocompatibility ${ }^{2-4}$ and thus they are also suitable for biomedical applications, such as laparoscopic surgery, stents, shape-memory microvalves, and osteosynthesis devices. ${ }^{5-7}$ It was reported that substituting Fe for Ni in TiNi SMAs induces the formation of the R-phase during the martensitic transformation and leads to some advanced mechanical properties superior to those of typical TiNi SMAs. ${ }^{89}$

W. J. Moberly et al. ${ }^{10}$ investigated the deformation, twinning and thermo-mechanical strengthening of $\mathrm{Ti}_{50} \mathrm{Ni}_{47} \mathrm{Fe}_{3}$ SMAs. Their results demonstrated that coldworked and annealed $\mathrm{Ti}_{50} \mathrm{Ni}_{47} \mathrm{Fe}_{3}$ SMAs had a refined subgrain size, a high yield strength, and a good ductility. In addition, several studies reported on TiNiFe SMAs with ultra-high internal-friction properties, which are excellent candidates for high-damping applications. ${ }^{11-13}$ Recently, D. Wang et al. ${ }^{14}$ established a complete temperature-composition phase diagram that included the pre-martensitic state, martensite and strain glass. They also reported that strain glass forms in TiNiFe SMAs when the Fe doping exceeds the critical value.

Several articles reveal that TiNiFe SMAs are candidate materials for biomedical applications. C. Li and Y. F. Zheng ${ }^{15}$ investigated the electrochemical behaviours of $\mathrm{Ti}_{50} \mathrm{Ni}_{47} \mathrm{Fe}_{3}$ SMAs and found that the surface of a $\mathrm{Ti}_{50} \mathrm{Ni}_{47} \mathrm{Fe}_{3}$ SMA mainly consists of $\mathrm{TiO}_{2}$, which is responsible for the good biocompatibility and anti-corrosion properties of the alloys. T. A. Tabish et al. ${ }^{16}$ further performed an in-vivo cytotoxic evaluation of TiNiFe SMAs and found that they do not exhibit any appreciable cytotoxic or systematic reactions to living systems. However, when SMAs are used as implant materials, interactions between the alloys and the living tissue can lead to the corrosion of the surface oxide layer, thereby increasing the risk of metal ions being released into the body. These metallic ions pose a 


\section{S.-H. CHANG et al.: SELECTIVE LEACHING AND SURFACE PROPERTIES OF TiNiFe SHAPE-MEMORY ALLOYS}

potential health hazard capable of inducing allergic reactions or even promoting the onset of cancer. ${ }^{17-19}$

Several researches had previously investigated the selective leaching behaviour of $\mathrm{TiNi}$ and $\mathrm{TiNiCu}$ $\mathrm{SMAs}^{20-23}$; however, the selective leaching of $\mathrm{Ti}, \mathrm{Ni}$, and $\mathrm{Fe}$ ions released from TiNiFe SMAs has not been studied. Therefore, this study investigated the selective leaching and surface properties of $\mathrm{Ti}_{50} \mathrm{Ni}_{50-\mathrm{x}} \mathrm{Fe}_{\mathrm{x}}(x=1,2$, and 3) SMAs using inductively coupled plasma mass spectrometry (ICP-MS), an X-ray diffraction (XRD) analysis, electrochemical tests, and X-ray photoelectron spectroscopy (XPS).

\section{EXPERIMENTAL PART}

The $\mathrm{Ti}_{50} \mathrm{Ni}_{50-\mathrm{x}} \mathrm{Fe}_{\mathrm{x}}(x=1,2$, and 3) SMAs used in this study were prepared from pure raw titanium (a purity of $99.9 \%$ mass fraction), nickel (a purity of $99.9 \%$ mass fraction), and iron (a purity of $99.98 \%$ mass fraction). The raw materials were re-melted using conventional vacuum arc remelting to form ingots in an argon atmosphere. Each ingot was hot-rolled at $900{ }^{\circ} \mathrm{C}$ using a rolling machine (DBR150x200 2HI-MILL, Daito Seiki Co, Japan) to form a $2 \mathrm{~mm}$ plates, which were then solution-heat-treated at $900{ }^{\circ} \mathrm{C}$ for $1 \mathrm{~h}$ and quenched in water. The surface oxide layer of a plate was removed using an etching solution of $\mathrm{HF}: \mathrm{HNO}_{3}: \mathrm{H}_{2} \mathrm{O}$ at a volume ratio of 1:5:20. Each plate was then cut into bulk samples with dimensions of $(30.0 \times 4.0 \times 2.0) \mathrm{mm}$ for characterization.

The crystallographic features of each $\mathrm{Ti}_{50} \mathrm{Ni}_{50-\mathrm{x}} \mathrm{Fe}_{\mathrm{x}}$ SMA were determined using a Rigaku IV XRD instrument with $\mathrm{Cu}-K \alpha$ radiation $(\lambda=0.154 \mathrm{~nm})$ at room temperature. The selective leaching properties of $\mathrm{Ti}_{50} \mathrm{Ni}_{50-\mathrm{x}} \mathrm{Fe}_{\mathrm{x}}$ SMAs were evaluated by immersing samples in test flasks containing $500 \mathrm{~mL}$ of Ringer's solution. Ringer's solution was used in selective-leaching tests because it is an isotonic solution similar to bodily fluids and is widely used in in-vitro experiments. Each test flask was maintained at $37{ }^{\circ} \mathrm{C}$ in an orbital shaker incubator for $80 \mathrm{~d}$. We then measured the concentrations of the released $\mathrm{Ti}, \mathrm{Ni}$, and Fe ions in Ringer's solution using ICP-MS (Agilent 7500ce).

Electrochemical measurements of the $\mathrm{Ti}_{50} \mathrm{Ni}_{50-\mathrm{x}} \mathrm{Fe}_{\mathrm{x}}$ SMAs were performed using an electrochemical workstation (ECW-5600, Jiehan) to determine the cathodic and anodic polarization Tafel curves, where a platinum plate was used as the counter electrode, a saturated calomel electrode (SCE) was used as the reference electrode and Ringer's solution was used as the test solution. The average corrosion potential $\left(E_{\text {corr }}\right)$ and the average corrosion current density $\left(i_{\text {corr }}\right)$ values of each specimen were calculated from seven Tafel curves, for which the maximum and minimum values were deleted. The surface chemical composition of the $\mathrm{Ti}_{50} \mathrm{Ni}_{50-\mathrm{x}} \mathrm{Fe}_{\mathrm{x}}$ SMAs was analysed using an XPS device (Thermo Scientific (VGS) K-Alpha) with a monochromatic Al-Ko radiation source of $1468.6 \mathrm{eV}$. The survey spectrum of each specimen was measured over a range of 200-1200 $\mathrm{eV}$ in 1-eV steps. High-resolution $\mathrm{Ti}, \mathrm{Ni}$, and $\mathrm{Fe} 2 \mathrm{p}$ spectra for each specimen were determined in $0.05-\mathrm{eV}$ steps. The XPSPeak 4.1 software was used for the analysis of XPS spectra.

\section{RESULTS \\ 3.1 XRD results}

Figure 1 presents the XRD results of the $\mathrm{Ti}_{50} \mathrm{Ni}_{50-\mathrm{x}} \mathrm{Fe}_{\mathrm{x}}$ SMAs, where each $\mathrm{Ti}_{50} \mathrm{Ni}_{50-\mathrm{x}} \mathrm{Fe}_{\mathrm{x}}$ SMA sample exhibits diffraction peaks related to $(110)_{\mathrm{B} 2}$, $(200)_{\mathrm{B} 2}$, and $(211)_{\mathrm{B} 2}$ at approximately $2 \theta=42.2^{\circ}, 61.3^{\circ}$, and $77.5^{\circ}$, respectively. Figure 1 further reveals that all of the $\mathrm{Ti}_{50} \mathrm{Ni}_{50-\mathrm{x}} \mathrm{Fe}_{\mathrm{x}}$ SMAs used in this study were in the parent phase at room temperature, indicating that the surface relief, which is normally observed at the R-phase, or the B19' martensite of TiNi-based SMAs, had no influence on the selective leaching.

\subsection{Selective leaching behaviours}

Figures $2 \mathbf{a}$ to $\mathbf{2 c}$ present the concentrations of the Ti, $\mathrm{Ni}$, and $\mathrm{Fe}$ ions, respectively, which were selectively leached from the $\mathrm{Ti}_{50} \mathrm{Ni}_{50-\mathrm{x}} \mathrm{Fe}_{\mathrm{x}} \mathrm{SMAs}$ in Ringer's solution as a function of the immersion time. Figure 2a shows that the concentration of the Ti ions selectively leached from the specimens was extremely low $\left(<1 \cdot 10^{-8}\right)$ throughout the $80 \mathrm{~d}$ of the immersion. Figure $\mathbf{2 b}$ shows that the concentrations of the Ni ions selectively leached from the $\mathrm{Ti}_{50} \mathrm{Ni}_{50-\mathrm{x}} \mathrm{Fe}_{\mathrm{x}} \mathrm{SMAs}$ were also extremely low during the first $30 \mathrm{~d}$; however, these concentrations increased significantly to above $1.5 \cdot 10^{-6} \mathrm{ppb}$ by day 80 . This feature indicates that the selective leaching rate of the $\mathrm{Ni}$ ions from the $\mathrm{Ti}_{50} \mathrm{Ni}_{50-\mathrm{x}} \mathrm{Fe}_{\mathrm{x}} \mathrm{SMAs}$ is considerably high. As shown in Figure 2c, the concentrations of the Fe ions selectively leached from the $\mathrm{Ti}_{50} \mathrm{Ni}_{50-\mathrm{x}} \mathrm{Fe}_{\mathrm{x}} \mathrm{SMAs}$

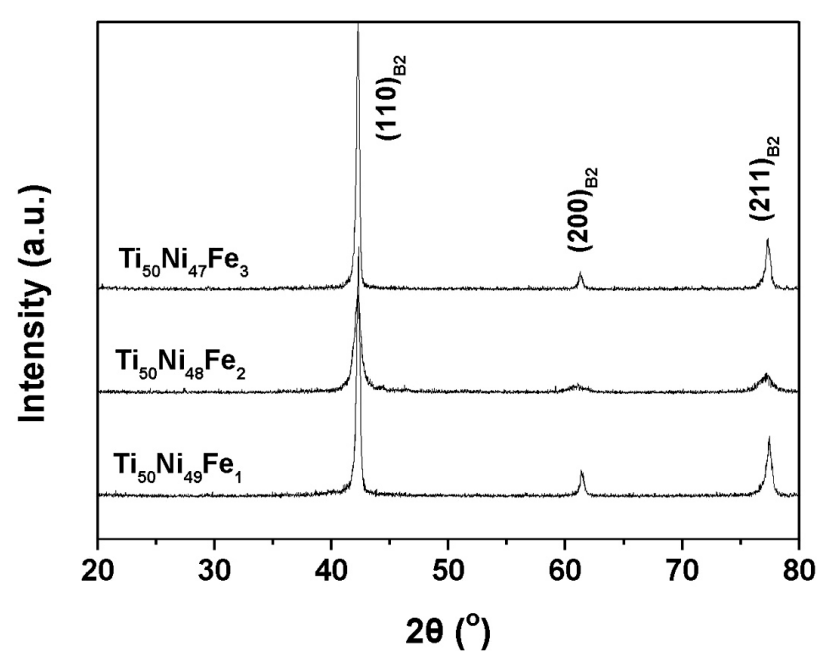

Figure 1: XRD pattern for $\mathrm{Ti}_{50} \mathrm{Ni}_{50-\mathrm{X}} \mathrm{Fe}_{\mathrm{X}}$ SMAs

Slika 1: Rentgenogram $\mathrm{Ti}_{50} \mathrm{Ni}_{50-\mathrm{X}} \mathrm{Fe}_{\mathrm{X}} \mathrm{SMA}$ 

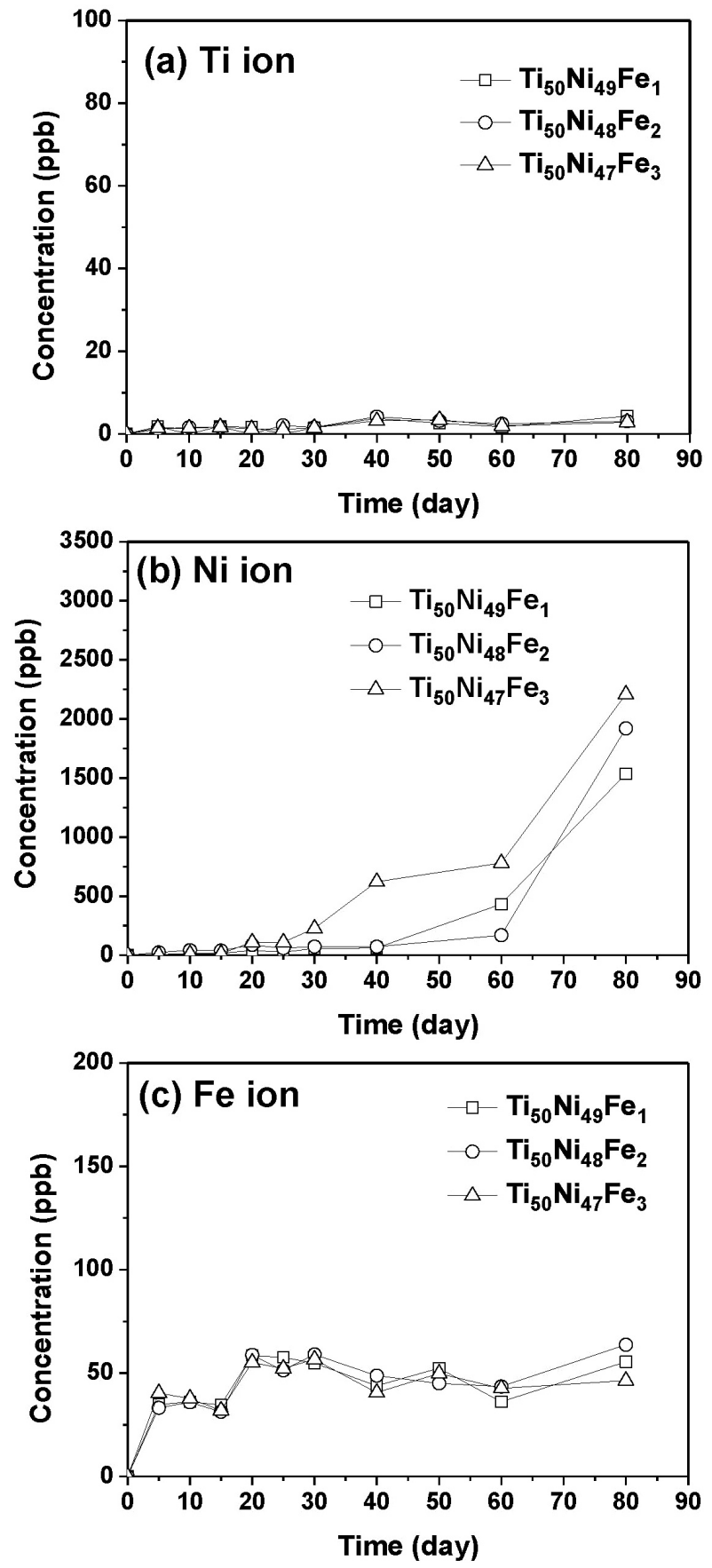

Figure 2: Concentrations of: a) $\mathrm{Ti}, \mathrm{b}$ ) $\mathrm{Ni}$, and c) $\mathrm{Fe}$ ions selectively leached from $\mathrm{Ti}_{50} \mathrm{Ni}_{50-\mathrm{x}} \mathrm{Fe}_{\mathrm{x}} \mathrm{SMAs}$

Slika 2: Koncentracije: a) Ti, b) Ni in c) Fe ionov, selektivno izpranih iz $\mathrm{Ti}_{50} \mathrm{Ni}_{50-\mathrm{x}} \mathrm{Fe}_{\mathrm{x}} \mathrm{SMA}$

were approximately $5 \cdot 10^{-8}$ after $80 \mathrm{~d}$. No obvious differences in the concentration of the Fe ions were observed among alloys with different chemical compositions. According to the results shown in Figure 2, the concentration of the $\mathrm{Ni}$ ions selectively leached from each of the specimens was considerably higher than that of the $\mathrm{Ti}$ and $\mathrm{Fe}$ ions, indicating that $\mathrm{Ni}$ ions are more easily released from the surface of $\mathrm{Ti}_{50} \mathrm{Ni}_{50-\mathrm{x}} \mathrm{Fe}_{\mathrm{x}} \mathrm{SMAs}$ than the $\mathrm{Ti}$ or Fe ions.

\subsection{Electrochemical properties}

Figure 3 presents the selected cathodic and anodic polarization Tafel curves obtained from Ringer's solution containing $\mathrm{Ti}_{50} \mathrm{Ni}_{50-\mathrm{x}} \mathrm{Fe}_{\mathrm{x}}$ SMAs. The average corrosion potential $\left(E_{\text {corr }}\right)$ and corrosion-current density $\left(i_{\text {corr }}\right)$ of each sample are listed in Table 1 . The $E_{\text {corr }}$ values of $\mathrm{Ti}_{50} \mathrm{Ni}_{50-\mathrm{x}} \mathrm{Fe}_{\mathrm{x}}$ SMAs gradually decreased from approximately $-0.379 \mathrm{~V}$ to $-0.433 \mathrm{~V}$ when the Fe content in the alloys was increased from 1 to 3 . This indicates that, when immersed in Ringer's solution, the $\mathrm{Ti}_{50} \mathrm{Ni}_{50-\mathrm{x}} \mathrm{Fe}_{\mathrm{x}}$ SMAs with a lower Fe content exhibit a better corrosion resistance, superior to that of the other SMAs. Table 1 also shows that, in the presence of an elevated $\mathrm{Fe}$ content, the $i_{\text {corr }}$ values of the $\mathrm{Ti}_{50} \mathrm{Ni}_{50-\mathrm{x}} \mathrm{Fe}_{\mathrm{x}}$ SMAs gradually increased from $(3.27 \pm 0.86) \times 10^{-7} \mathrm{~A} / \mathrm{cm}^{2}$ to $(5.52 \pm 1.05) \times 10^{-6} \mathrm{~A} / \mathrm{cm}^{2}$, demonstrating a gradual increase in the corrosion rate of the $\mathrm{Ti}_{50} \mathrm{Ni}_{50-x} \mathrm{Fe}_{\mathrm{x}}$ SMAs when alloys had a higher Fe content.

Table 1: The average $E_{\text {corr }}$ and $I_{\text {corr }}$ values determined according to the cathodic and anodic polarization Tafel curves from Figure 3

Tabela 1: Srednje vrednosti $E_{\text {corr }}$ in $I_{\text {corr }}$ določene pri katodni in anodni polarizaciji iz Taflovih krivulj iz Slike 3

\begin{tabular}{|c|c|c|}
\hline Sample & $\begin{array}{c}\text { Avg. } E_{\text {corr }} \\
(\mathrm{V})\end{array}$ & $\begin{array}{c}\text { Avg. } I_{\text {corr }} \\
\left(\mathrm{A} / \mathrm{cm}^{2}\right)\end{array}$ \\
\hline $\mathrm{Ti}_{50} \mathrm{Ni}_{49} \mathrm{Fe}_{1}$ & $-0.379 \pm 0.017$ & $(3.27 \pm 0.68) \times 10^{-7}$ \\
\hline $\mathrm{Ti}_{50} \mathrm{Ni}_{48} \mathrm{Fe}_{2}$ & $-0.394 \pm 0.006$ & $(3.54 \pm 0.66) \times 10^{-6}$ \\
\hline $\mathrm{Ti}_{50} \mathrm{Ni}_{47} \mathrm{Fe}_{3}$ & $-0.433 \pm 0.007$ & $(5.52 \pm 1.05) \times 10^{-6}$ \\
\hline
\end{tabular}

\section{$3.3 X$-ray photoelectron spectroscopy}

Figures $4 \mathbf{a}$ to $\mathbf{4} \mathbf{c}$ present the XPS survey spectra of the $\mathrm{Ti}_{50} \mathrm{Ni}_{49} \mathrm{Fe}_{1}, \mathrm{Ti}_{50} \mathrm{Ni}_{48} \mathrm{Fe}_{2}$, and $\mathrm{Ti}_{50} \mathrm{Ni}_{47} \mathrm{Fe}_{3}$ SMAs, respectively. Each specimen exhibited significant characteristic peaks associated with Ti (a Ti $2 \mathrm{p}$ peak at approximately $460 \mathrm{eV}$ ), Ni (a Ni 2p peak at approximately 853 $\mathrm{eV}$ ), $\mathrm{O}$ (an $\mathrm{O} 1 \mathrm{~s}$ peak at approximately $531 \mathrm{eV}$ ), and contamination C (a C 1s peak at approximately $285 \mathrm{eV}$ ).

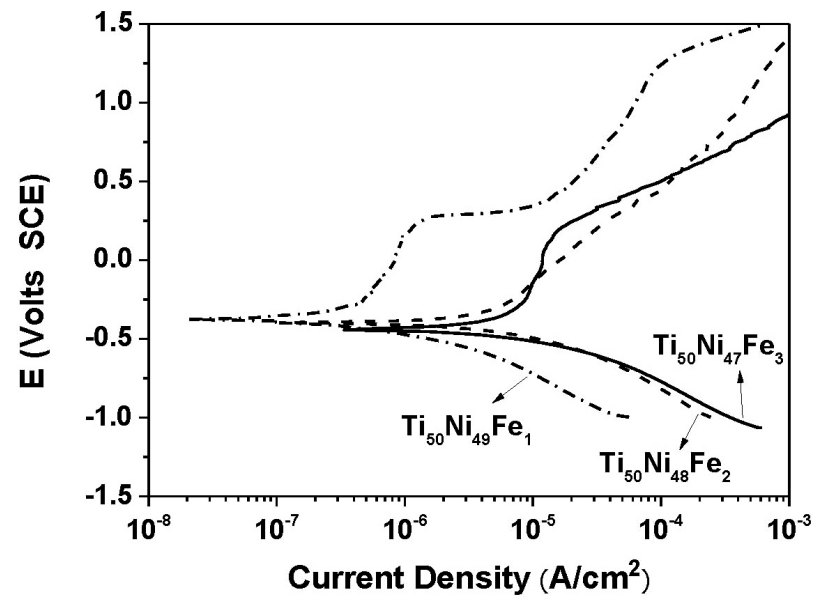

Figure 3: Cathodic and anodic polarization Tafel curves for $\mathrm{Ti}_{50} \mathrm{Ni}_{50-\mathrm{x}} \mathrm{Fe}_{\mathrm{x}} \mathrm{SMAs}$

Slika 3: Taflova krivulja katodne in anodne polarizacije $\mathrm{Ti}_{50} \mathrm{Ni}_{50-\mathrm{x}} \mathrm{Fe}_{\mathrm{X}}$ SMAs 
(a) $\mathrm{Ti}_{50} \mathrm{Ni}_{49} \mathrm{Fe}_{1}$ Survey

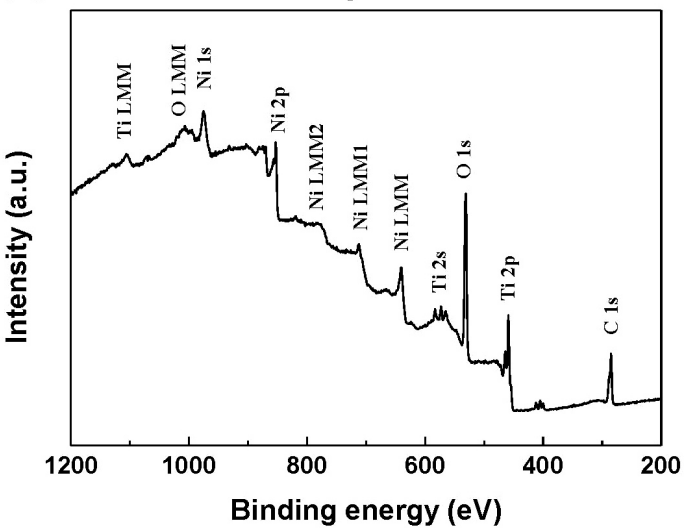

(b) $\mathrm{Ti}_{50} \mathrm{Ni}_{48} \mathrm{Fe}_{2}$ Survey

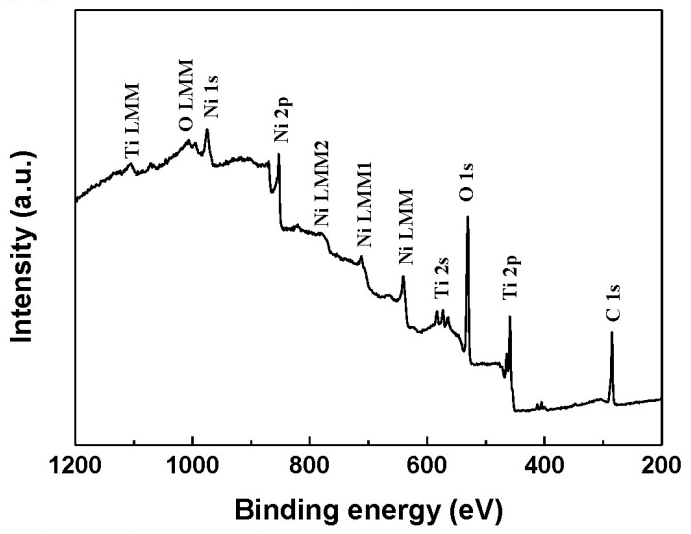

(c) $\mathrm{Ti}_{50} \mathrm{Ni}_{47} \mathrm{Fe}_{3}$ Survey

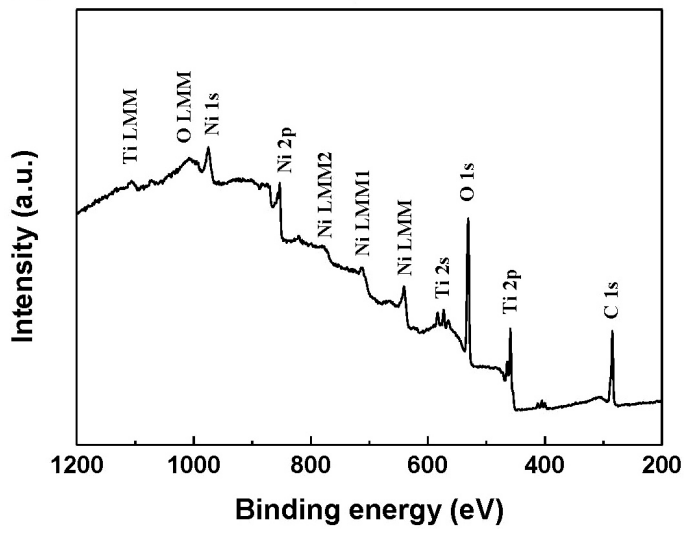

Figure 4: XPS survey spectra of the surfaces of: a) $\mathrm{Ti}_{50} \mathrm{Ni}_{49} \mathrm{Fe}_{1}$, b) $\mathrm{Ti}_{50} \mathrm{Ni}_{48} \mathrm{Fe}_{2}$, and c) $\mathrm{Ti}_{50} \mathrm{Ni}_{47} \mathrm{Fe}_{3}$ SMAs

Slika 4: XPS-spektri površin: a) $\mathrm{Ti}_{50} \mathrm{Ni}_{49} \mathrm{Fe}_{1}$, b) $\mathrm{Ti}_{50} \mathrm{Ni}_{48} \mathrm{Fe}_{2}$ in c) $\mathrm{Ti}_{50} \mathrm{Ni}_{47} \mathrm{Fe}_{3} \mathrm{SMAs}$

Figure 4 also reveals an insignificant Fe $2 p$ peak at approximately $710 \mathrm{eV}$ for each specimen.

Figures 5a to $\mathbf{5 c}$ present the Ti 2p XPS spectra of the $\mathrm{Ti}_{50} \mathrm{Ni}_{49} \mathrm{Fe}_{1}, \mathrm{Ti}_{50} \mathrm{Ni}_{48} \mathrm{Fe}_{2}$, and $\mathrm{Ti}_{50} \mathrm{Ni}_{47} \mathrm{Fe}_{3}$ SMAs, respectively. Figure 5a shows that the Ti $2 p$ characteristic peaks of the $\mathrm{Ti}_{50} \mathrm{Ni}_{49} \mathrm{Fe}_{1}$ SMA can be divided into four oxidation states, $\mathrm{Ti}^{4+}, \mathrm{Ti}^{3+}, \mathrm{Ti}^{2+}$, and $\mathrm{Ti}^{0}$, corresponding to $\mathrm{TiO}_{2}, \mathrm{Ti}_{2} \mathrm{O}_{3}$, TiO, and metallic $\mathrm{Ti}$, respectively. ${ }^{24-26}$ As shown in Figure 5a, the $\mathrm{TiO}_{2}$ peak was more prominent than the other peaks, indicating that $\mathrm{TiO}_{2}$ was the domi-

\section{(a) $\mathrm{Ti}_{50} \mathrm{Ni}_{49} \mathrm{Fe}_{1} \mathrm{Ti} 2 \mathrm{p}$}

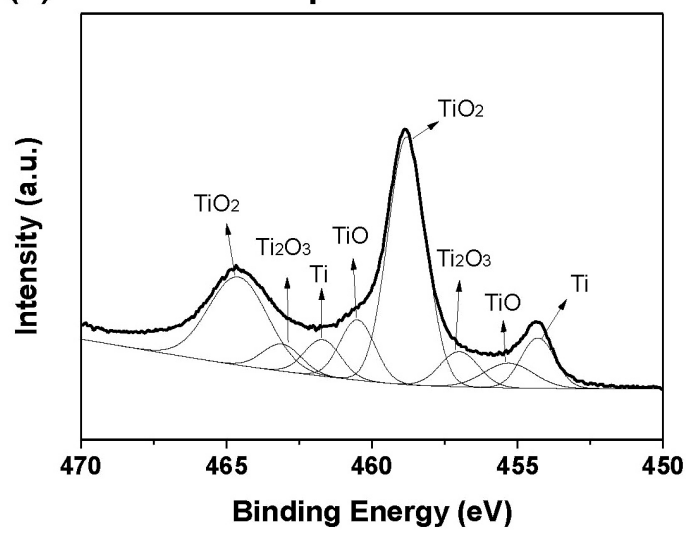

(b) $\mathrm{Ti}_{50} \mathrm{Ni}_{48} \mathrm{Fe}_{2} \mathrm{Ti} 2 \mathrm{p}$

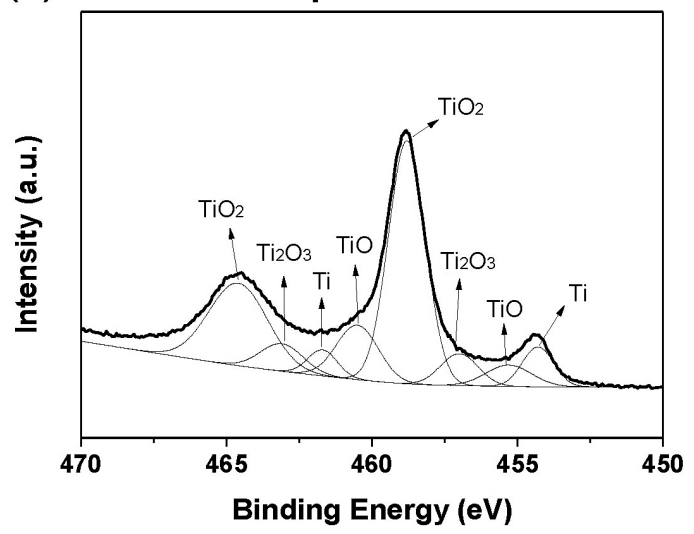

(c) $\mathrm{Ti}_{50} \mathrm{Ni}_{47} \mathrm{Fe}_{3} \mathrm{Ti} 2 \mathrm{p}$

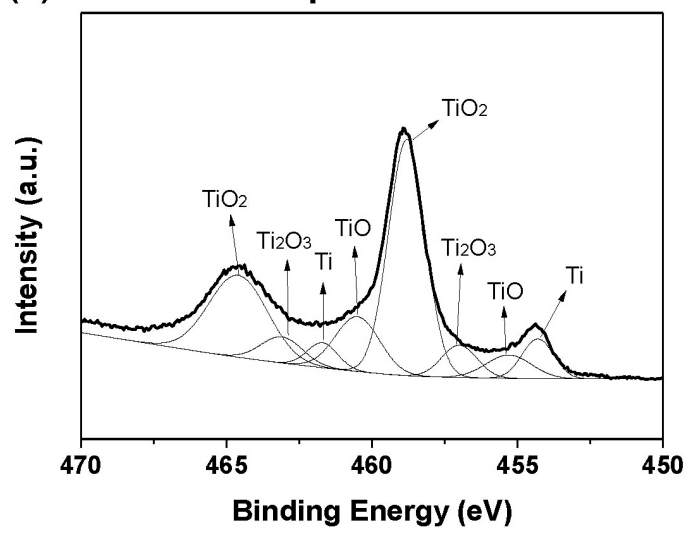

Figure 5: Ti $2 p$ XPS spectra of the surfaces of: a) $\mathrm{Ti}_{50} \mathrm{Ni}_{49} \mathrm{Fe}_{1}$, b) $\mathrm{Ti}_{50} \mathrm{Ni}_{48} \mathrm{Fe}_{2}$, and c) $\mathrm{Ti}_{50} \mathrm{Ni}_{47} \mathrm{Fe}_{3} \mathrm{SMAs}$

Slika 5: Ti 2p XPS spektri površin: a) $\mathrm{Ti}_{50} \mathrm{Ni}_{49} \mathrm{Fe}_{1}$, b) $\mathrm{Ti}_{50} \mathrm{Ni}_{48} \mathrm{Fe}_{2}$ in c) $\mathrm{Ti}_{50} \mathrm{Ni}_{47} \mathrm{Fe}_{3} \mathrm{SMAs}$

nant oxide layer on the surface of the $\mathrm{Ti}_{50} \mathrm{Ni}_{49} \mathrm{Fe}_{1}$ SMA. Figures $\mathbf{5 b}$ and $\mathbf{5 c}$ show that the Ti $2 \mathrm{p}$ XPS spectra of the $\mathrm{Ti}_{50} \mathrm{Ni}_{48} \mathrm{Fe}_{2}$ and $\mathrm{Ti}_{50} \mathrm{Ni}_{47} \mathrm{Fe}_{3}$ SMAs were very similar to that of the $\mathrm{Ti}_{50} \mathrm{Ni}_{49} \mathrm{Fe}_{1}$ SMA shown in Figure 5a. This suggests that the surfaces of the $\mathrm{Ti}_{50} \mathrm{Ni}_{48} \mathrm{Fe}_{2}$ and $\mathrm{Ti}_{50} \mathrm{Ni}_{47} \mathrm{Fe}_{3}$ SMAs were also primarily composed of a $\mathrm{TiO}_{2}$ oxide layer.

Figures $6 \mathbf{a}$ to $\mathbf{6} \mathbf{c}$ present the Ni $2 \mathrm{p}$ XPS spectra of the $\mathrm{Ti}_{50} \mathrm{Ni}_{49} \mathrm{Fe}_{1}, \mathrm{Ti}_{50} \mathrm{Ni}_{48} \mathrm{Fe}_{2}$, and $\mathrm{Ti}_{50} \mathrm{Ni}_{47} \mathrm{Fe}_{3}$ SMAs, respectively. Figure 6a shows that the $\mathrm{Ni} 2 \mathrm{p}$ characteristic 
(a) $\mathrm{Ti}_{50 \mathrm{Ni}}{ }_{49} \mathrm{Fe}_{1} \mathrm{Ni2p}$

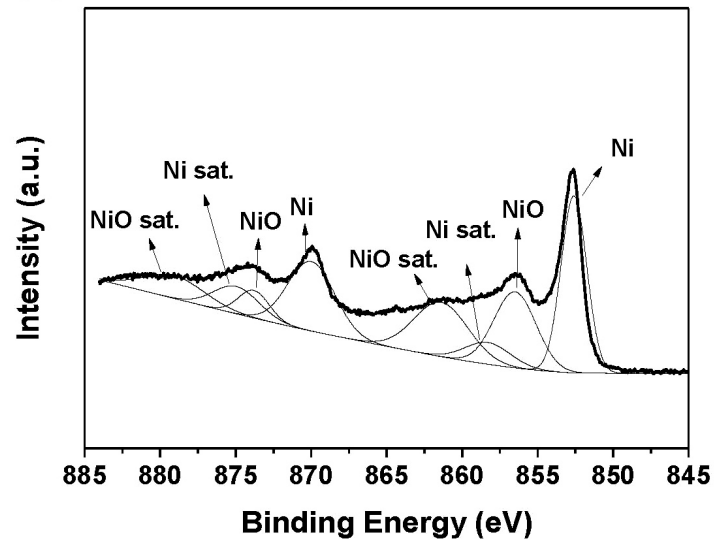

(b) $\mathrm{Ti}_{50} \mathrm{Ni}_{48} \mathrm{Fe}_{2} \mathrm{Ni2p}$

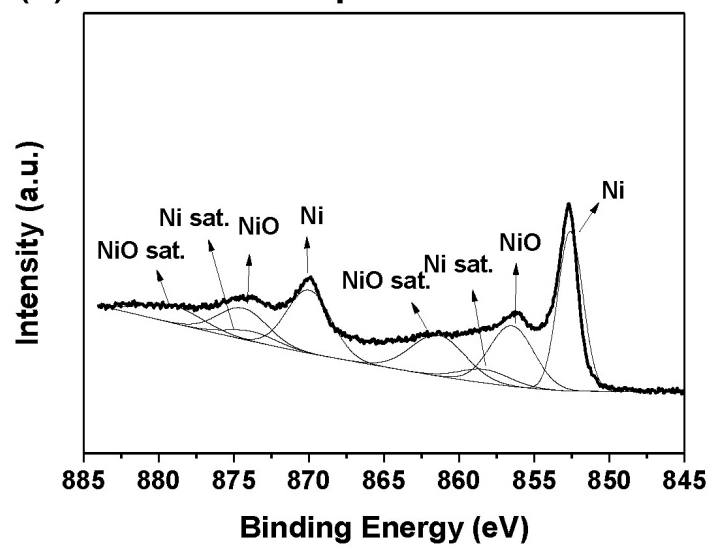

(c) $\mathrm{Ti}_{50} \mathrm{Ni}_{47} \mathrm{Fe}_{3} \mathrm{Ni} 2 \mathrm{p}$

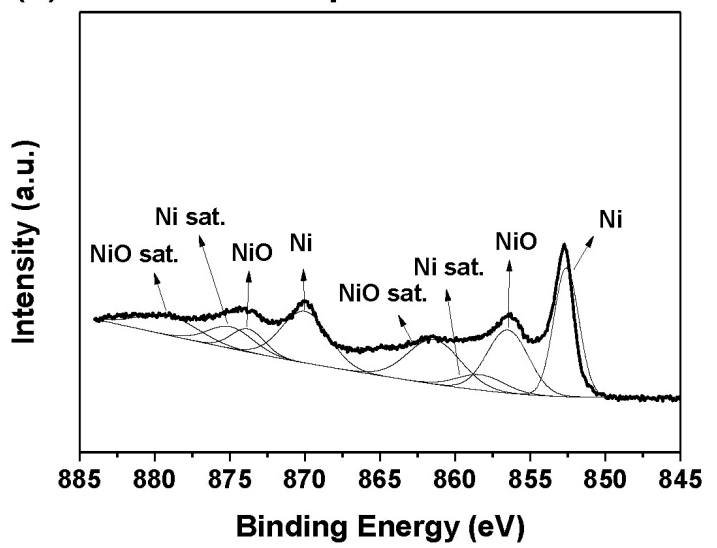

Figure 6: Ni $2 \mathrm{p}$ XPS spectra of the surfaces of: a) $\mathrm{Ti}_{50} \mathrm{Ni}_{49} \mathrm{Fe}_{1}$, b) $\mathrm{Ti}_{50} \mathrm{Ni}_{48} \mathrm{Fe}_{2}$, and c) $\mathrm{Ti}_{50} \mathrm{Ni}_{47} \mathrm{Fe}_{3} \mathrm{SMAs}$

Slika 6: $\mathrm{Ni} 2 \mathrm{p}$ XPS-spektri površin: a) $\mathrm{Ti}_{50} \mathrm{Ni}_{4} \mathrm{Fe}_{1}$, b) $\mathrm{Ti}_{50} \mathrm{Ni}_{48} \mathrm{Fe}_{2}$ in c) $\mathrm{Ti}_{50} \mathrm{Ni}_{47} \mathrm{Fe}_{3} \mathrm{SMA}$

peaks of the $\mathrm{Ti}_{50} \mathrm{Ni}_{49} \mathrm{Fe}_{1}$ SMA can be divided into the metallic-Ni and NiO-oxidation states. We also observed two small shoulders corresponding to the satellite (sat.) peaks of the metallic $\mathrm{Ni}$ and $\mathrm{NiO}$ near the characteristic peaks. Figures $\mathbf{6 b}$ and $\mathbf{6} \mathbf{c}$ show that the Ni $2 \mathrm{p}$ XPS spectra of the $\mathrm{Ti}_{50} \mathrm{Ni}_{48} \mathrm{Fe}_{2}$ and $\mathrm{Ti}_{50} \mathrm{Ni}_{47} \mathrm{Fe}_{3}$ SMAs were nearly identical to that of the $\mathrm{Ti}_{50} \mathrm{Ni}_{49} \mathrm{Fe}_{1}$ SMA, suggesting an abundance of metallic $\mathrm{Ni}$ atoms on the (a) $\mathrm{Ti}_{50} \mathrm{Ni}_{49} \mathrm{Fe}_{1} \mathrm{Fe} 2 \mathrm{p}$

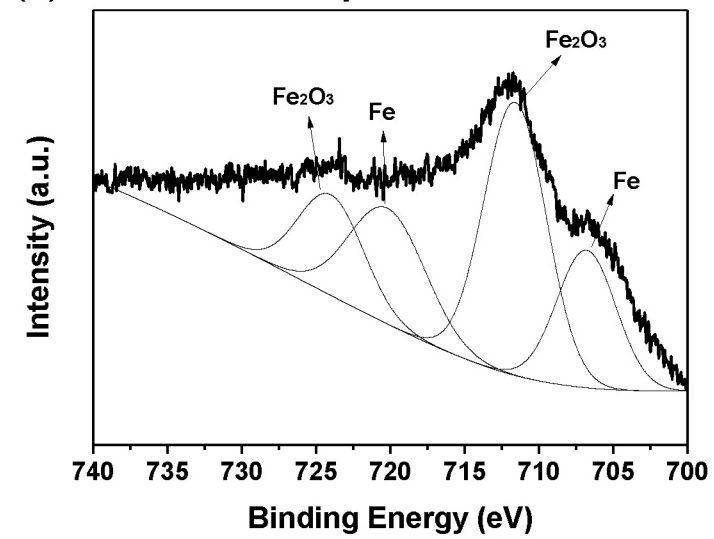

(b) $\mathrm{Ti}_{50} \mathrm{Ni}_{48} \mathrm{Fe}_{2} \mathrm{Fe} 2 \mathrm{p}$

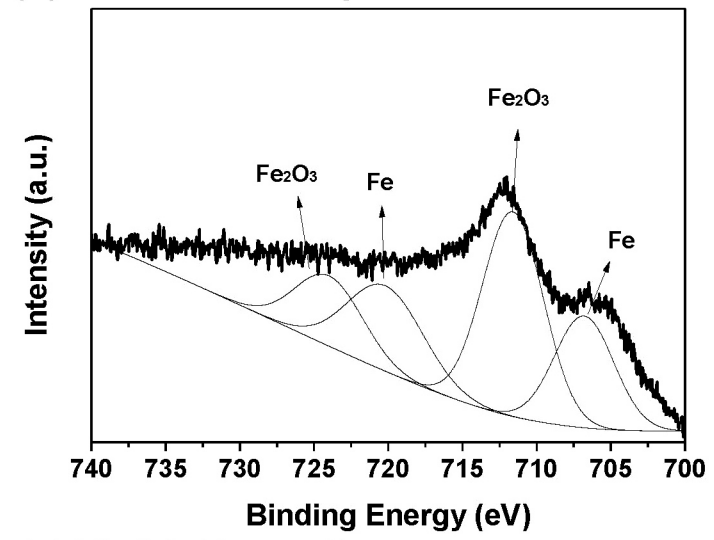

(c) $\mathrm{Ti}_{50} \mathrm{Ni}_{47} \mathrm{Fe}_{3} \mathrm{Fe} 2 \mathrm{p}$

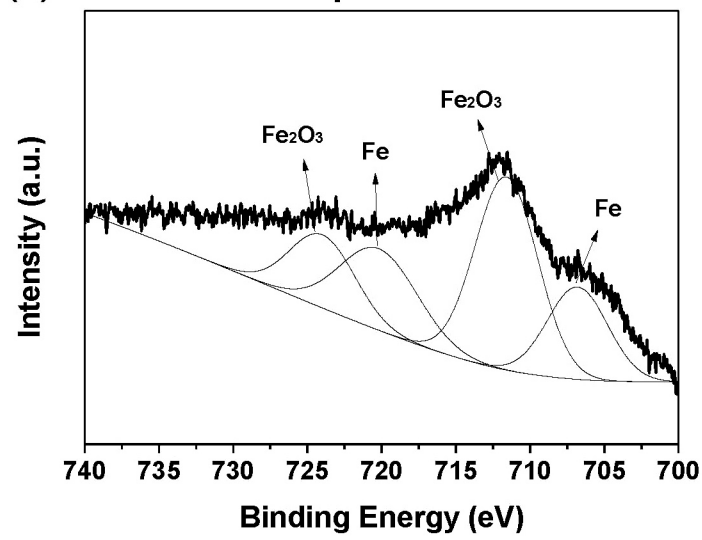

Figure 7: $\mathrm{Fe} 2 \mathrm{p}$ XPS spectra of the surfaces of: a) $\mathrm{Ti}_{50} \mathrm{Ni}_{49} \mathrm{Fe}_{1}$, b) $\mathrm{Ti}_{50} \mathrm{Ni}_{48} \mathrm{Fe}_{2}$, and c) $\mathrm{Ti}_{50} \mathrm{Ni}_{47} \mathrm{Fe}_{3} \mathrm{SMAs}$

Slika 7: Fe 2p XPS-spektri površin: a) $\mathrm{Ti}_{50} \mathrm{Ni}_{49} \mathrm{Fe}_{1}$, b) $\mathrm{Ti}_{50} \mathrm{Ni}_{48} \mathrm{Fe}_{2}$ in c) $\mathrm{Ti}_{50} \mathrm{Ni}_{47} \mathrm{Fe}_{3} \mathrm{SMA}$

surfaces of $\mathrm{Ti}_{50} \mathrm{Ni}_{50-\mathrm{x}} \mathrm{Fe}_{\mathrm{x}} \mathrm{SMAs}$. Figures 7a to 7c present the Fe 2p XPS spectra of the $\mathrm{Ti}_{50} \mathrm{Ni}_{49} \mathrm{Fe}_{1}, \mathrm{Ti}_{50} \mathrm{Ni}_{48} \mathrm{Fe}_{2}$, and $\mathrm{Ti}_{50} \mathrm{Ni}_{47} \mathrm{Fe}_{3}$ SMAs, respectively. Compared to the XPS spectra of $\mathrm{Ti} 2 \mathrm{p}$ and $\mathrm{Ni} 2 \mathrm{p}$ in Figures 5 and $\mathbf{6}$, the intensity of the Fe $2 \mathrm{p}$ XPS spectrum was relatively low. Figures 7a to 7c show that the Fe $2 p$ characteristic peaks of the $\mathrm{Ti}_{50} \mathrm{Ni}_{50-x} \mathrm{Fe}_{\mathrm{x}}$ SMAs can be divided into $\mathrm{Fe}_{2} \mathrm{O}_{3}$ and metallic $\mathrm{Fe}$ peaks, in which $\mathrm{Fe}_{2} \mathrm{O}_{3}$ is the dominant oxide characterizing the surfaces of $\mathrm{Ti}_{50} \mathrm{Ni}_{50-\mathrm{x}} \mathrm{Fe}_{\mathrm{x}} \mathrm{SMAs}$. 


\section{DISCUSSION}

According to the Ti 2p XPS spectra in Figure 5, the $\mathrm{Ti}$ atoms near the surfaces of the $\mathrm{Ti}_{50} \mathrm{Ni}_{50-\mathrm{x}} \mathrm{Fe}_{\mathrm{x}} \mathrm{SMAs}$ were covered mainly with a film of a $\mathrm{TiO}_{2}$ oxide. This result can be explained with a high thermodynamic stability of $\mathrm{TiO}_{2} \cdot{ }^{27-30}$ Furthermore, the $\mathrm{TiO}_{2}$ films that formed on the surfaces of $\mathrm{Ti}_{50} \mathrm{Ni}_{50-\mathrm{x}} \mathrm{Fe}_{\mathrm{x}}$ SMAs are highly corrosion resistant, which leads to extremely low selective leaching of the Ti ions, as demonstrated in Figure 2a. In contrast, Figure $\mathbf{2 b}$ shows that comparatively higher concentrations of $\mathrm{Ni}$ ions were leached from the $\mathrm{Ti}_{50} \mathrm{Ni}_{50-\mathrm{x}} \mathrm{Fe}_{\mathrm{x}}$ SMAs, indicating that the selective leaching rate of the $\mathrm{Ni}$ ions was much higher than that of the $\mathrm{Ti}$ ions, which was, in turn, due to an abundance of metallic $\mathrm{Ni}$ atoms on the surfaces of the $\mathrm{Ti}_{50} \mathrm{Ni}_{50-\mathrm{x}} \mathrm{Fe}_{\mathrm{x}} \mathrm{SMAs}$, as shown in Figure 6. Figure $\mathbf{2 b}$ also reveals that the concentrations of the $\mathrm{Ni}$ ions selectively leached from the $\mathrm{Ti}_{50} \mathrm{Ni}_{50-\mathrm{x}} \mathrm{Fe}_{\mathrm{x}}$ SMAs gradually increased with an increase in the Fe content in the $\mathrm{Ti}_{50} \mathrm{Ni}_{50-\mathrm{x}} \mathrm{Fe}_{\mathrm{x}}$ SMAs. This corresponds to the fact that the corrosion resistance of the $\mathrm{Ti}_{50} \mathrm{Ni}_{50-x} \mathrm{Fe}_{\mathrm{x}}$ SMAs gradually deteriorated with an increase in the Fe content of the alloys, as revealed by Figure 3. As shown in Figure 2c, the concentration of the $\mathrm{Fe}$ ions selectively leached from the $\mathrm{Ti}_{50} \mathrm{Ni}_{50-x} \mathrm{Fe}_{\mathrm{x}}$ SMAs was approximately $50 \mathrm{ppb}$, which is much lower than that of the Ni ions. This is a direct consequence of the fact that the Fe content in the $\mathrm{Ti}_{50} \mathrm{Ni}_{50-\mathrm{x}} \mathrm{Fe}_{\mathrm{x}} \mathrm{SMAs}$ was below 3 atomic percent. As shown in Figure 7, this finding also corresponds to the fact that most $\mathrm{Fe}$ atoms on the surface of a specimen were in the form of $\mathrm{Fe}_{2} \mathrm{O}_{3}$ oxides, rather than metallic Fe.

A previous study found that extremely low concentrations of $\mathrm{Ti}$ and $\mathrm{Ni}$ ions were selectively leached from $\mathrm{Ti}_{50} \mathrm{Ni}_{50}$ SMAs and attributed this to a passive $\mathrm{TiO}_{2}$ surface film inhibiting the ion movement. ${ }^{23}$ However, during the current study, we observed high concentrations of selectively leached $\mathrm{Ni}$ and $\mathrm{Fe}$ ions. This suggests that the $\mathrm{NiO}$ and $\mathrm{Fe}_{2} \mathrm{O}_{3}$ oxides that formed on the surfaces of the $\mathrm{Ti}_{50} \mathrm{Ni}_{50-\mathrm{x}} \mathrm{Fe}_{\mathrm{x}}$ SMAs caused a deterioration of the uniformity of the $\mathrm{TiO}_{2}$ oxide films and, therefore, of their protective effect. Thus, despite the fact that the $\mathrm{Ti}_{50} \mathrm{Ni}_{50-\mathrm{x}} \mathrm{Fe}_{\mathrm{x}}$ SMAs exhibit a number of properties not found in the other SMAs, the high concentrations of selectively leached $\mathrm{Ni}$ and $\mathrm{Fe}$ ions may pose a health risk in biomedical applications. A further surface modification is necessary if the $\mathrm{Ti}_{50} \mathrm{Ni}_{50-x} \mathrm{Fe}_{\mathrm{x}}$ SMAs are to be considered as implantation materials in human bodies.

\section{CONCLUSION}

All of the $\mathrm{Ti}_{50} \mathrm{Ni}_{50-x} \mathrm{Fe}_{\mathrm{x}}$ SMAs used in this study were in the parent phase during the selective leaching tests. The concentrations of the Ti ions selectively leached from the $\mathrm{Ti}_{50} \mathrm{Ni}_{50-\mathrm{x}} \mathrm{Fe}_{\mathrm{x}} \mathrm{SMAs}$ were extremely low because the Ti atoms near the surface of the alloys underwent oxidization to form passive $\mathrm{TiO}_{2}$ films. The concentration of the $\mathrm{Ni}$ ions selectively leached from the
$\mathrm{Ti}_{50} \mathrm{Ni}_{50-x} \mathrm{Fe}_{\mathrm{x}}$ SMAs gradually increased with an increase in the Fe content in the $\mathrm{Ti}_{50} \mathrm{Ni}_{50-x} \mathrm{Fe}_{\mathrm{x}} \mathrm{SMAs}$, which can be explained with the fact that the corrosion resistance inversely correlated with the Fe content in the alloys. The concentrations of the $\mathrm{Fe}$ ions selectively leached from the $\mathrm{Ti}_{50} \mathrm{Ni}_{50-x} \mathrm{Fe}_{\mathrm{x}} \mathrm{SMAs}$ were approximately $5 \times$ higher than those of the Ti ions. The high concentrations of the $\mathrm{Ni}$ and $\mathrm{Fe}$ ions released from the $\mathrm{Ti}_{50} \mathrm{Ni}_{50-\mathrm{x}} \mathrm{Fe}_{\mathrm{x}}$ SMAs were probably caused by the fact that the $\mathrm{NiO}$ and $\mathrm{Fe}_{2} \mathrm{O}_{3}$ oxides, formed on the surfaces of the $\mathrm{Ti}_{50} \mathrm{Ni}_{50-\mathrm{x}} \mathrm{Fe}_{\mathrm{x}}$ SMAs reduced the uniformity of the $\mathrm{TiO}_{2}$ oxide films and thereby compromised the protective effect of the films. Selectively leached $\mathrm{Ni}$ and $\mathrm{Fe}$ ions may pose a risk in biomedical applications; therefore, a surface modification is required if the $\mathrm{Ti}_{50} \mathrm{Ni}_{50-\mathrm{x}} \mathrm{Fe}_{\mathrm{x}} \mathrm{SMAs}$ are to be used as implant materials.

\section{Acknowledgements}

The authors gratefully acknowledge the financial support for this research provided by the Ministry of Science and Technology (MOST), Taiwan, Republic of China, under Grant No. MOST103-2221-E-197-007.

\section{REFERENCES}

${ }^{1}$ K. Otsuka, X. Ren, Physical metallurgy of Ti-Ni-based shape memory alloys, Progress in Materials Science, 50 (2005) 5, 511-678, doi:10.1016/j.pmatsci.2004.10.001

${ }^{2}$ M. Assad, N. Lemieux, C. H. Rivard, L'H. Yahia, Comparative in vitro biocompatibility of nickel-titanium, pure nickel, pure titanium, and stainless steel: genotoxicity and atomic absorption evaluation, Bio-Medical Materials and Engineering, 9 (1999) 1, 1-12

${ }^{3}$ M. Es-Souni, M. Es-Souni, H. F. Brandies, Assessing the biocompatibility of NiTi shape memory alloys used for medical applications, Analytical and Bioanalytical Chemistry, 381 (2005) 3, 557-567, doi:10.1007/s00216-004-2888-3

${ }^{4}$ M. Assad, A. Chernyshov, M. A. Leroux, C. H. Rivard, A new porous titanium-nickel alloy: Part 1, Cytotoxicity and genotoxicity evaluation, Bio-Medical Materials and Engineering, 12 (2002) 3, 225-237

${ }^{5}$ P. Filip, J. Lausmaa, J. Musialek, K. Mazanec, Structure and surface of TiNi human implants, Biomaterials, 22 (2001) 15, 2131-2138, doi:10.1016/S0142-9612(00)00404-X

${ }^{6}$ K. Kuribayashi, K. Tsuchiya, Z. You, D. Tomus, M. Umemoto, T. Ito, M. Sasaki, Self-deployable origami stent grafts as a biomedical application of Ni-rich TiNi shape memory alloy foil, Materials Science and Engineering, A 419 (2006) 1-2, 131-137, doi:10.1016/ j.msea.2005.12.016

${ }^{7}$ J. Y. Xiong, Y. C. Li, X. J. Wang, P. D. Hodgson, C. E. Wen, Titanium-nickel shape memory alloy foams for bone tissue engineering, Journal of the Mechanical Behavior of Biomedical Materials, 1 (2008) 3, 269-273, doi:10.1016/j.jmbbm.2007.09.003

${ }^{8}$ E. Goo, T. Duerig, K. Melton, R. Sinclair, Mechanical twinning in $\mathrm{Ti}_{50} \mathrm{Ni}_{47} \mathrm{Fe}_{3}$ and $\mathrm{Ti}_{49} \mathrm{Ni}_{51}$ alloys, Acta Metallurgica, 33 (1985) 9, 1725-1733, doi:10.1016/0001-6160(85)90167-1

${ }^{9}$ C. M. Hwang, C. M. Wayman, Phase transformations in TiNiFe, TiNiAl and TiNi alloys, Scripta Metallurgica, 17 (1983) 11, 1345-1350, doi:10.1016/0036-9748(83)90230-2

${ }^{10}$ W. J. Moberly, J. L. Proft, T. W. Duerig, R. Sinclair, Deformation, twinning and thermo-mechanical strengthening of $\mathrm{Ti}_{50} \mathrm{Ni}_{47} \mathrm{Fe}_{3}$, Acta Metallurgica et Materialia, 38 (1990) 12, 2601-2612, doi:10.1016/ 0956-7151(90)90272-I 


\section{MATERIALI IN TEHNOLOGIJE/MATERIALS AND TECHNOLOGY (1967-2017) - 50 LET/50 YEARS}

\section{S.-H. CHANG et al.: SELECTIVE LEACHING AND SURFACE PROPERTIES OF TiNiFe SHAPE-MEMORY ALLOYS}

${ }^{11}$ G. Fan, Y. Zhou, K. Otsuka, X. Ren, Ultrahigh damping in R-phase state of Ti-Ni-Fe alloy, Applied Physics Letters, 89 (2006) 16, 161902, doi:10.1063/1.2363173

${ }^{12}$ I. Yoshida, D. Monma, T. Ono, Damping characteristics of $\mathrm{Ti}_{50} \mathrm{Ni}_{47} \mathrm{Fe}_{3}$ alloy, Journal of Alloys and Compounds, 448 (2008) 1-2, 349-354, doi:10.1016/j.jallcom.2007.04.217

${ }^{13}$ G. Fan, Y. Zhou, K. Otsuka, X. Ren, T. Suzukib, F. Yin, Comparison of the two relaxation peaks in the $\mathrm{Ti}_{50} \mathrm{Ni}_{48} \mathrm{Fe}_{2}$ alloy, Materials Science and Engineering, A, 521-522 (2009) 15, 178-181, doi:10.1016/ j.msea.2008.09.086

${ }^{14}$ D. Wang, Z. Zhang, J. Zhang, Y. Zhou, Y. Wang, X. Ding, Y. Wang, $\mathrm{X}$. Ren, Strain glass in Fe-doped Ti-Ni, Acta Materialia, 58 (2010) 18, 6206-6215, doi:10.1016/j.actamat.2010.07.040

${ }^{15} \mathrm{C}$. Li, Y. F. Zheng, The electrochemical behavior of a $\mathrm{Ti}_{50} \mathrm{Ni}_{47} \mathrm{Fe}_{3}$ shape memory alloy, Materials Letters, 60 (2006)13-14, 1646-1650, doi:10.1016/j.matlet.2005.11.097

${ }^{16}$ T. A. Tabish, T. Z. Butt, M. Ali, M. Ali, R. S. Shaikh, S. Atiq, L. Draghi, In vivo cytotoxic evaluation of $\mathrm{Ti}-\mathrm{Ni}-\mathrm{Fe}$ shape memory alloys, Materials Technology: Advanced Performance Materials, 29 (2014) 3, 139-143, doi:10.1179/1753555713Y.0000000091

${ }^{17}$ K. Takamura, K. Hayashi, N. Ishinishi, T. Yamada, Y. Sugioka, Evaluation of carcinogenicity and chronic toxicity associated with orthopedic implants in mice, Journal of Biomedical Materials Research, 28 (1994) 5, 583-589, doi:10.1002/jbm.820280508

${ }^{18}$ H. Takahashi, M. Kinbara, N. Sato, K. Sasaki, S. Sugawara, Y. Endo, Nickel allergy-promoting effects of microbial or inflammatory substances at the sensitization step in mice, International Immunopharmacology, 11 (2011) 10, 1534-1540, doi:10.1016/j.intimp. 2011.05.010

${ }^{19}$ V. D’Antò, A. Eckhardt, K. A. Hiller, G. Spagnuolo, R. Valletta, L. Ambrosio, G. Schmalz, H. Schweikl, The influence of Ni(II) on surface antigen expression in murine macrophages, Biomaterials, 30 (2009) 8, 1492-1501, doi:10.1016/j.biomaterials.2008.12.004

${ }^{20}$ C. L. Chu, C. Guo, X. B. Sheng, Y. S. Dong, P. H. Lin, K. W. K. Yeung, P. K. Chu, Microstructure, nickel suppression and mechanical characteristics of electropolished and photoelectrocatalytically oxidized biomedical nickel titanium shape memory alloy, Acta Biomaterialia, 5 (2009) 6, 2238-2245, doi:10.1016/j.actbio.2009.01.046

${ }^{21}$ E. Espinar, J. M. Llamas, A. Michiardi, M. P. Ginebra, F. J. Gil, Reduction of Ni release and improvement of the friction behaviour of NiTi orthodontic archwires by oxidation treatments, Journal of Materials Science, Materials in Medicine, 22 (2011), 1119-1125, doi:10.1007/s10856-011-4292-9
${ }^{22}$ F. J. Gil, E. Espinar, J. M. Llamas, J. M. Manero, M. P. Ginebra, Variation of the superelastic properties and nickel release from original and reused NiTi orthodontic archwires, Journal of the Mechanical Behavior of Biomedical Materials, 6 (2012), 113-119, doi:10.1016/j.jmbbm.2011.11.005

${ }^{23} \mathrm{~S}$. H. Chang, W. C. Chiu, Selective leaching and surface properties of $\mathrm{Ti}_{50} \mathrm{Ni}_{50-\mathrm{x}} \mathrm{Cu}_{\mathrm{x}}(\mathrm{x}=0-20 \%$ of amount fractions) shape memory alloys for biomedical applications, Applied Surface Science, 324 (2015), 106-113, doi:10.1016/j.apsusc.2014.10.030

${ }^{24}$ Y. W. Gu, B. Y. Tay, C. S. Lim, M. S. Yong, Characterization of bioactive surface oxidation layer on NiTi alloy, Applied Surface Science, 252 (2005) 5, 2038-2049, doi:10.1016/j.apsusc.2005.03.207

${ }^{25}$ R. M. Wang, C. L. Chu, T. Hu, Y. S. Dong, C. Guo, X. B. Sheng, P. H. Lin, C.Y. Chung, P. K. Chu, Surface XPS characterization of NiTi shape memory alloy after advanced oxidation processes in $\mathrm{UV} / \mathrm{H}_{2} \mathrm{O}_{2}$ photocatalytic system, Applied Surface Science, 253 (2007) 20, 8507-8512, doi:10.1016/j.apsusc.2007.04.018

${ }^{26}$ C. L. Chu, C. Guo, X. B. Sheng, Y. S. Dong, P. H. Lin, K. W. K. Yeung, P. K. Chu, Microstructure, nickel suppression and mechanical characteristics of electropolished and photoelectrocatalytically oxidized biomedical nickel titanium shape memory alloy, Acta Biomaterialia, 5 (2009) 6, 2238-2245, doi:10.1016/j.actbio.2009. 01.046

${ }^{27}$ C. L. Chu, C.Y. Chung, P. K. Chu, Surface oxidation of NiTi shape memory alloy in a boiling aqueous solution containing hydrogen peroxide, Materials Science and Engineering A, 417 (2006) 1-2, 104-109, doi:10.1016/j.msea.2005.11.010

${ }^{28}$ D. Vojtěch, M. Voděrová, J. Fojt, P. Novák, T. Kubásek, Surface structure and corrosion resistance of short-time heat-treated NiTi shape memory alloy, Applied Surface Science, 257 (2010) 5, 1573-1582, doi:10.1016/j.apsusc.2010.08.097

${ }^{29}$ S. A. Shabalovskaya, G. C. Rondelli, A. L. Undisz, J. W. Anderegg, T. D. Burleigh, M. E. Rettenmayr, The electrochemical characteristics of native Nitinol surfaces, Biomaterials, 30 (2009) 22, 3662-3671, doi:10.1016/j.biomaterials.2009.03.034

${ }^{30}$ S. A. Shabalovskaya, H. Tian, J. W. Anderegg, D. U. Schryvers, W. U. Carroll, J. Van Humbeeck, The influence of surface oxides on the distribution and release of nickel from Nitinol wires, Biomaterials, 30 (2009) 4, 468-477, doi:10.1016/j.biomaterials.2008.10.014 